JPPUMA: Jurnal Ilmu Pemerintahan dan Sosial Politik UMA Uournal of Governance and Political Social UMA), 7 (2) (2019): 102-110, DOI: http://dx.doi.org/10.31289/ippuma.v7i2.2887

JPPUMA: Jurnal Ilmu Pemerintahan dan Sosial Politik UMA (Journal of Governance and Political Social UMA)

\title{
Perilaku Memilih Pemegang Kartu Tani pada Pemilihan Gubernur Jawa Tengah 2018 di Kabupaten Semarang
}

\section{Choosing Behaviour Farmer Card Holders in Central Java 2018 Election Governor on Semarang District Malisa Ladini'1) \& Yuwanto's)}

\author{
1)Program Studi Magister Ilmu Politik, Fakultas Ilmu Sosial dan Ilmu Politik, \\ Universitas Diponegoro, Indonesia \\ 2) Program Studi Doktor Ilmu Sosial, Fakultas Ilmu Sosial dan Ilmu Politik, \\ Universitas Diponegoro, Indonesia
}

Diterima: 14 September 2019; Disetujui 18 November 2019; Dipublikasikan 01 Desember 2019

\begin{abstract}
Abstrak
Penelitian ini bertujuan untuk menganalisis faktor yang mempengaruhi perilaku memilih petani pemegang kartu tani dalam Pemilihan Gubenur Jawa Tengah 2018 di Kabupaten Semarang serta jenis perilaku memilih petani pemegang kartu tani dalam memberikan suara. Metode penelitian yang digunakan dalam penelitian ini merupakan metode penelitian kuantitatif sederhana yang didukung dengan pendekatan deskriptif dengan pendekatan kualitatif. Teknik pengumpulan data kuantitatif menggunakan survai dan pengumpulan kualitatif menggunakan teknik wawancara mendalam dan dokumentasi. Hasil penelitian dan pembahasan penelitian ini menunjukkan perilaku petani dipengaruhi empat faktor, yaitu sosiologis, psikologis, pertimbangan rasional atau insensif, dan domain koginitif. Untuk faktor sosiologis, dipengaruhi persahabatan atau hubungan keluarga. Faktor psikologis karena mereka keteratrikan secara pribadi pada sosok Ganjar. Faktor insentif karena mereka sering dibantu oleh partai pendukung Ganjar. Faktor domain kognitif, petani memilih karena mereka manfaat kartu tani. Petani pemegang kartu tani memberikan suaranya karena tokoh dan juru kampanye. Simpulan dari penelitian ini yaitu petani yang pemegang kartu tani di Kabupaten Semarang lebih memilih Paslon 1 Ganjar Pranowo-Taj Yasin.
\end{abstract}

Kata Kunci: Perilaku Memilih, Petani, Kartu, Pemilihan Kepala Daerah

\section{Abstract}

The benefits of the research to analyze the factors that influence the behavior of selecting farmers who hold farmers card in the Election Governor of Central Java 2018 in Semarang Regency. The research method is a quantitative research that is supported by a descriptive approach with a qualitative approach. Quantitative data collection techniques using surveys and qualitative collection using in-depth interview and documentation. The results of the research and discussion of this study indicate that the behavior of farmers is influenced by four factors, namely sociological, psychological, rational, and coginitive domains. For sociological factors, because is influended by friendship or family relations. Psychological factors because likes to the figure of Ganjar. Incentive factor because they are often assisted by Ganjar supporters. Cognitive domain factors, farmers choose because kindness from the presence of farmer cards. Farmer card holders give their votes because emotional ties to respected figures in their neighborhood who are members of campaigners. But there was also the phenomenon abstentions in Bancak District due to apathy towards the existence of a peasant card policy. The conclusion is that farmers who hold farmers card in Semarang Regency prefer Paslon 1 Ganjar Pranowo-Taj Yasin.

Keywords: Voting Behavior, Farmers, Cards, Local Elections.

How to Cite: Ladini. M. \& Yuwanto (2019). Perilaku Memilih Pemegang Kartu Tani Pada Pemilihan Gubernur Jawa Tengah 2018 Kabupaten Semarang. JPPUMA: Jurnal Ilmu Pemerintahan dan Sosial Politik UMA (Journal of Governance and Political Social UMA), 7 (1): 102-110 


\section{PENDAHULUAN}

Pemilihan umum Gubernur Jawa Tengah 2018 (selanjutnya disebut Pilgub Jateng 2018) dilaksanakan pada 27 Juni 2018 untuk menentukan Gubernur serta Wakil Gubernur dengan masa jabatan 5 tahun periode 2018-2023. Pemilihan Gubernur Jawa Tengah Tahun 2018 diikuti oleh dua pasangan yaitu Paslon 1. Ganjar Pranowo/Taj Yasin Maimoen yang dicalonkan oleh PDI P, Demokrat, PPP, Nasdem serta Paslon 2 Sudirman Said-Ida Fauziah yang dicalonkan oleh PKB, Gerindra, PAN, dan PKS. Salah satu kelompok masyarakat yang ikut serta dalam Pemilihan Gubernur 2018 ialah kelompok petani. Petani merupakan elemen masyarakat yang cukup banyak dan memiliki khas tersendiri. Sebagaimana Rizkiyansyah (2007) mengatakan bahwa "Pemilihan Umum adalah salah satu pranata yang paling representatif atas berjalannya demokrasi, tidak pernah ada demokrasi tanpa pemilihan umum".

Data Infrastruktur dan Sumber Daya Alam Provinsi Jawa Tengah menunjukkan bahwa jumlah petani di Jawa Tengah sebanyak 2.878.968 jiwa dengan luas lahan seluas 1.552.285 Ha. Dari jumlah tersebut, petani di Jawa Tengah yang sudah mendapatkan kartu tani sebanyak 84,69\% atau sebanyak 2.438.288 jiwa. Manfaat dari penerbitan kartu tani ialah sebagaidatabase tunggal pertanian yang dapat dimanfaatkan stakeholder dalam menentukan kebijakan dan memonitoring penyaluran bantuan. Sistem kartu tani mencakup adanya data RDKK (Rancangan Dasar Kebutuhan Kelompok) sehingga kebutuhan pupuk petani disesuaikan dengan lahan yang dimilikinya. (Lumansyah, 2018, Inilah Manfaat Kartu Tani Bagi Bank dan Petani, https://industri.kontan.co.id/news/inimanfaat-kartu-tani-bagi-petani-dan-bank Diakses pada 27 Januari 2018 Pukul 23.17 WIB)

Menurut data Biro Isda Jawa Tengah 2019, jumlah petani di Kabupaten
Semarang ialah sebanyak 91.062 orang dengan luas lahan sebanyak 45.110 dan petani pemegang kartu tani sebesar $86,43 \%$ atau sebanyak 78.730 orang. Program kartu tani ternyata memunculkan persoalan di Kabupaten Semarang. Persoalan petani di Kecamatan Bancak Kabupaten Semarang terjadi karena kesulitan akses untuk memiliki kartu tani. Kurangnya sosialisasikepadapetani membuat mereka mengalami kesulitan dalam pengurusan kartu tani ke bank mitra. (Munir, 2019, Syahrul Munir, Petani di Semarang Tak Bisa Tebus Pupuk Bersubsidi diambil dari https://regional.kompas.com/read/2018/ 02/15/16375931/petani-di-semarangtak-bisa-tebus-pupuk-bersubsidi pada tanggal 7 Januari 2019 Pukul 13.40 WIB).

Persoalan mengenaikartu tani disampaikan oleh anggota Komisi B DPRD Provinsi Jawa karena pendataan petani yang masih belum selesai. Data yang dibutuhkan ialah data petani, kepemilikan lahan, hasil panen, dan stok komoditas. (Ellya, 2018, Ironis Kartu Tani Dijanjikan Selesai Akhir Masa Jabatan Ganjat, diakses dari http://beritajateng.net/ironis-kartutani-dijanjikan-selesai-akhir-jabatan-

ganjar/ pada tanggal 15 Januari 2018 Pukul 02.02 WIB). Permasalahan kartu tani di sejumlah kabupaten menjadi isu politik menjelang Pemilihan Gubernur Jawa Tengah 2018. (Elza, 2018, https://news.detik.com/berita/3893512/ sudirman-said-bakal-hapus-kartu-taniganjar-pranowo diakses pada Selasa, 15 Januari 2019 Pukul 21.49). Paslon 2 Sudirman Said dan Ida Fauziah mengkritik kartu tani yang tidak berjalan secara memuaskan karena adanya kesalahan pendataan petani melalui e-KTP. Sudirman Said akan menghapus program Kartu Tani dan berjanji akan mengganti dengan program baru yaitu Program Tani Mandiri saat menyampaikan program kerja yang ditawarkan kepada media. Kemudian kritikan Paslon 2 mengenai kartu tani juga disampaikan dalam Debat Gubernur Jawa 
Tengah. (Nurdin, 2018, Debat Ganjar dan Sudirman Said tentang Kartu Tani" diambil dari

https://regional.kompas.com/read/2018/ 04/21/06315441/debat-ganjar-dansudirman-said-tentang-kartu-tani diakses pada Selasa, 15 Januari 2019 Pukul 21.55 WIB). Meskipun kritikan program kartu tani dimunculkan oleh Paslon 2 Sudirman Said-Ida Fauziah, tapi Paslon 1 Ganjar Pranowo-Taj Yasin masih dinyatakan menang dalam Pemilihan Gubernur Jawa Tengah 2018. Ganjar Pranowo dan Taj Yasin menang di 31 kabupaten/kota dari 35 kabupaten/kota.

Menurut (Utomo, 2013) Pola perilaku memilih Jawa Tengah pada umumnya selalu berorientasi pada Figure yang memliki kedekatan emosional dengan pemilih partai pendukungnya, merupakan antiklimak pola perilaku memilih yang pragmatistransaksional. Hasil penelitian lain, Fitriyah (2013) meunnjukkan bahwa kemenangan figure Pilkada yang menang didukung oleh pemilih dengan dengan karakteristik yang khas.

Perilaku memilih ialah proses kegiatan warga negara untuk membuat keputusan dalam politik, baik itu yaitu apakah memilih atau tidak memilih dalam pemilihan umum (Surbakti, 1992). Mar'at (1996) mengatakan sesorang bereaksi apabila rangsangan koumunikator diterima oleh komunikan.

Jika memilih apakah memilih partai tertentu atau memilih kandidat tertentu. Sastroatmodjo (1995) mengemukakan bahwa "sikap politik dinyatakan lewat reakssi objek yang bersifat politik". Berdasarkan sikap politik akan dapat diperkirakan perilaku politik apa yang akan muncul.

Adman Nursal membagi pendekatan perilaku pemilih ke dalam beberapa pendekatan (Nursal, 2004). Pertama pendekatan Sosiologis. Pendekatann sosiologis ialah keputusan memilih pada konteks sosial. Pendekatan tingkah laku politik yang dipengaruhi identifikasi diri terhadap kelompok, termasuk norma yang dianut oleh kelompok tersebut.

Kedua, pendekatan psikologis. Pendekatan sikap dan sosialisasi untuk perilaku pemilih. Pendekatan psikologis menganggap sikap untuk menjelaskan perilaku politik.

Ketiga, pendekatan rasional. Pendekatan rasional berorientasi isu dan orientasi kandidat. Perilaku pemilih berorientasi isu yang akan memerintah dan mengatasi semua persoalan yang masyarakat (Schulz, 1998).

Keempat, pendekatan domain kognitif. Kepercayaan kognitif dari sumber seperti pemilih, mulut ke mulut, dan media massa. Model ini dikembangkan untuk menerangkan dalam memprediksi pemilih.

Firmansyah mengatakan bahwa kampanye lebih merupakan suatu ajang manuver politik bagi pemilih dalam pemilu sehingga bisa meraih kekuasaan. Pemilu telah selesai, maka mereka melupakan segala janji (Firmanzyah, 2007). Sejalan dengan apa yang dikatakan oleh Schumpeter dalam Sorensen (2009) meumuskan pengertian demokrasi secara sederhana, kampanye merupakan sebuah metode politik, sebuah mekanisme untuk memilih pemimpin politik. Terlebih bagi kaum tani, Mosher (1995) mengatakan bahwa pertanian ialah produksi yang khas, yang didasarkan pada proses pertumbuhan tanaman. Petani juga memiliki tingkatan seperti petani penggarap dan tuan tanah (Anwas, 1992).

\section{METODE PENELITIAN}

Penelitian ini menggunakan metode penelitian kuantitatif sederhana yang didukung dengan pendekatan deskriptif dengan pendekatan kualitatif. Fokus penelitian merupakan domain tunggal atau beberapa domain yang terkait dari situasi sosial (Sugiyono, 2010).

Fokus penelitian ini membahas tentang faktor-faktor yang mempengaruhi perilaku memilih petani pemegang kartu tani dalam Pemilihan Gubernur Jawa 
Tengah 2018 di Kabupaten Semarang, setelah mengetahui faktor-faktornya maka bisa dianalisis bagaimana perilaku pemilih petani pemegang kartu tani dalam Pemilihan Gubernur Jawa Tengah 2018 di Kabupaten Semarang dan. Lokasi penelitian di Kabupaten Semarang. Data primer dari penelitian ini adalah data hasil wawancara dengan para narasumber serta hasil survai dengan para petani pemegang kartu tani di Kabupaten Semarang. Petani ada perbedaan bagi yang aktif dalam kelompok dan tidak. Biasanya yang aktif lebih aktif dalam politik (Adiwilanga, 1992). Data sekunder dari penelitian ini adalah Data Penerima Kartu Tani di Kabupaten Semarang di Dinas Pertanian di Kabupaten Semarang. Informan dalam penelitian kualitatif adalah petani pemegang kartu tani. Informan adalah orang yang bisa memberikan informasiinformasi utama yang dibutuhkan dalam penelitian (Prastowo, 2012)

Reseponden penelitian kuantitatif penlitian ini sejumlah 100 sampel dalam pnelitian ini tersebar ke 6 kecamatan, yaitu kecamatan Ungaran Timur, Ungaran Barat, Pringapus, Bergas, Ambarawa, dan Bancak. Pengolahan data kuantitatif diperoleh melalui metode survei dengan menggunakan angket dan diolah menggunakan statistik deskriptif yang berupa skala lirket dan prosentase yang diolah dengan teknik pengukuran skor. Teknik pengukuran skor dalam penelitian ini menggunakan teknik penilaian skala Likert. Model Analisis Interaksi (interactive analysis models) ialah teknik analisis data dimana komponen reduksi data dan sajian data dilakukan bersamaan dengan proses pengumpulan data. Analisis menggunakan (reduksi data, sajian data, penarikan kesimpulan) saling berinteraksi.

\section{HASIL DAN PEMBAHASAN}

Faktor sosiologis perilaku memilih petani menunjukkan bahwa perilaku memilih petani pemegang kartu tani dalam Pemilihan Gubernur 2018 di Kabupaten
Semarang dapat diranking pada tiap indikatornya. Dalam faktor sosiologis, adanya hubungan pertemanan dan keluarga dengan paslon atau pun partai pengusung paslon mempengaruhi perilaku pemilih petani pemegang kartu tani. Jadi dapat disimpulkan bahwa petani pemegang kartu tani tidak memilih Sudirman Said-Ida Fauziah karena petani tidak bisa mengidentifikasi Paslon 2 karena merupakan orang baru bagi para petani. Representasi pemilihan secara faktor sosiologis ialah sebagai berikut:

\begin{tabular}{|c|c|c|c|}
\hline No & Kecamatan & Hasil & Hasil \\
\hline 1 & Pringapus & Memilih Paslon 1 & $78 \%$ \\
\hline 2 & Pringapus & $\begin{array}{ll}\text { Tidak } & \text { Memilih } \\
\text { Paslon 2 } & \end{array}$ & $41 \%$ \\
\hline 3 & Bergas & Memilih Paslon 1 & $68,42 \%$ \\
\hline 4 & Bergas & $\begin{array}{ll}\text { Tidak } & \text { Memilih } \\
\text { Paslon } 2 & \end{array}$ & $49 \%$ \\
\hline 5 & $\begin{array}{l}\text { Ungaran } \\
\text { Barat }\end{array}$ & Memilih Paslon 1 & $78,11 \%$ \\
\hline 6 & $\begin{array}{l}\text { Ungaran } \\
\text { Barat }\end{array}$ & $\begin{array}{l}\text { Tidak } \\
\text { Paslon } 2\end{array}$ & $51 \%$ \\
\hline 7 & $\begin{array}{l}\text { Ungaran } \\
\text { Timur }\end{array}$ & Memilih Paslon 1 & $81,7 \%$ \\
\hline 8 & $\begin{array}{l}\text { Ungaran } \\
\text { Timur }\end{array}$ & $\begin{array}{r}\text { Memilih } \\
2\end{array}$ & $49 \%$ \\
\hline 9 & Bancak & $\begin{array}{l}\text { Belum Tentu } \\
\text { Memilih Paslon } 1\end{array}$ & $63 \%$ \\
\hline 10 & Bancak & $\begin{array}{ll}\text { Tidak } & \text { Memilih } \\
\text { Paslon2 } & \end{array}$ & $45 \%$ \\
\hline 11 & Ambarawa & $\begin{array}{l}\text { Belum Tentu } \\
\text { Memilih Paslon } 1\end{array}$ & $67 \%$ \\
\hline 12 & Ambarawa & $\begin{array}{ll}\text { Tidak } & \text { Memilih } \\
\text { Paslon } 2 & \end{array}$ & $52 \%$ \\
\hline
\end{tabular}

Sumber Tabel: Hasil Penelitian di Lapangan

Berdasarkan tabel tersebut, petani pemegang kartu tani di Kecamatan Pringapus, Kecamatan Bergas, Kecamatan Ungaran Barat, dan Kecamatan Ungaran Timur didapatkan hasil lebih memilih Paslon 1 (Ganjar Pranowo-Taj Yasin) dalam Pemilihan Gubernur Jawa Tengah Tahun 2018.

Secara psikologis, petani memiliki ketertarikan emosional dengan figure Ganjar. Tapi muncul fenomena golput di beberapa kecamatan seperti di Kecamatan Bancak dan Kecamatan Ambarawa karena 
mereka memiliki sikap apatis kepada pilgub dan kartu tani.

Faktor psikologis perilaku memilih menunjukkan bahwa etelah ranking tiap indikator atau faktor psikologis dihitung, maka didapatkan hasil ranking antara pemilih petani yang memilih Paslon 1 atau pun paslon 2. Hasil tersebut sebagai berikut.

Tabel 1 Faktor Psikologis Perilaku Memilih Petani

\begin{tabular}{|c|c|c|c|}
\hline No & Kecamatan & Hasil & Hasil \\
\hline 1 & Pringapus & Memilih Paslon 1 & $75 \%$ \\
\hline 2 & Pringapus & $\begin{array}{l}\text { Tidak Memilih } \\
\text { Paslon } 2\end{array}$ & $40 \%$ \\
\hline 3 & Bergas & Memilih Paslon 1 & $68,1 \%$ \\
\hline 4 & Bergas & $\begin{array}{l}\text { Tidak Memilih } \\
\text { Paslon } 2\end{array}$ & $44 \%$ \\
\hline 5 & Ungaran Barat & Memilih Paslon 1 & $76 \%$ \\
\hline 6 & Ungaran Barat & $\begin{array}{l}\text { Belum Tentu } \\
\text { Memilih Paslon } 2\end{array}$ & $57 \%$ \\
\hline 7 & Ungaran Timur & Memilih Paslon 1 & $74,6 \%$ \\
\hline 8 & Ungaran Timur & $\begin{array}{l}\text { Belum Tentu } \\
\text { Memilih Paslon } 2\end{array}$ & $53,6 \%$ \\
\hline 9 & Bancak & $\begin{array}{lr}\text { Tidak } & \text { Memilih } \\
\text { Paslon } & 1\end{array}$ & $63 \%$ \\
\hline 10 & Bancak & $\begin{array}{lr}\text { Tidak } & \text { Memilih } \\
\text { Paslon } & 2\end{array}$ & $50 \%$ \\
\hline 11 & Ambarawa & $\begin{array}{l}\text { Tidak Memilih } \\
\text { Paslon } 1\end{array}$ & $48 \%$ \\
\hline 12 & Ambarawa & $\begin{array}{l}\text { Tidak Memilih } \\
\text { Paslon } 2\end{array}$ & $52 \%$ \\
\hline
\end{tabular}

Sumber Tabel: Hasil Penelitian di Lapangan

Berdasarkan hasil yang didapat, dari enam kecamatan ada dua kecamatan yang menyatakan tidak memilih kedua paslon atau golput dengan faktor psikologis yaitu kecamatan Bancak dan Kecamatan Ambarawa.

Secara rasional, petani juga lebih memilih Paslon 1 karena adanya bantuanbantuan yang diterima oleh petani melalui partai pendukungnya. Ranking antara pemilih petani yang memilih Paslon 1 atau pun paslon 2. Hasil tersebut sebagai berikut.

Faktor rasional perilaku memilih petani menunjukkan bahwa setelah ranking tiap indikator atau faktor rasional dihitung, maka didapatkan hasil ranking antara pemilih petani yang memilih Paslon
1 atau pun paslon 2. Hasil tersebut sebagai berikut.

Tabel 1 Faktor Rasional Perilaku Memilih Petani

\begin{tabular}{|c|c|c|c|}
\hline No & Kecamatan & Hasil & Hasil \\
\hline 1 & Pringapus & Memilih Paslon 1 & $81 \%$ \\
\hline 2 & Pringapus & $\begin{array}{l}\text { Tidak Memilih } \\
\text { Paslon } 2\end{array}$ & $47 \%$ \\
\hline 3 & Bergas & $\begin{array}{l}\text { Belum Memilih } \\
\text { Paslon } 1\end{array}$ & $60,26 \%$ \\
\hline 4 & Bergas & $\begin{array}{l}\text { Tidak Memilih } \\
\text { Paslon } 2\end{array}$ & $42,10 \%$ \\
\hline 5 & Ungaran Barat & Memilih Paslon 1 & $75 \%$ \\
\hline 6 & Ungaran Barat & $\begin{array}{lr}\text { Tidak } & \text { Memilih } \\
\text { Paslon } & 2\end{array}$ & $48 \%$ \\
\hline 7 & Ungaran Timur & Memilih Paslon 1 & $90,71 \%$ \\
\hline 8 & Ungaran Timur & $\begin{array}{lr}\text { Tidak } & \text { Memilih } \\
\text { Paslon } & 2\end{array}$ & $50 \%$ \\
\hline 9 & Bancak & $\begin{array}{l}\text { Belum Tentu } \\
\text { Memilih Paslon } 1\end{array}$ & 61,17 \\
\hline 10 & Bancak & $\begin{array}{lr}\text { Pasti } & \text { Memilih } \\
\text { Paslon } & 2\end{array}$ & $88 \%$ \\
\hline 11 & Ambarawa & $\begin{array}{l}\text { Belum Tentu } \\
\text { Memilih Paslon } 1\end{array}$ & $61 \%$ \\
\hline 12 & Ambarawa & $\begin{array}{l}\text { Belum Tentu } \\
\text { Memilih Paslon } 2\end{array}$ & $61 \%$ \\
\hline
\end{tabular}

Sumber Tabel: Hasil Penelitian di Lapangan

Berdasarkan tabel tersebut, petani pemegang kartu tani di Kecamatan Pringapus dan Kecamatan Bergas didapatkan hasil belum tentu memilih Paslon 1 dan tidak memilih Paslon 2 dengan faktor rasional. Kemudian untuk Kecamatan Ungaran Barat didapatkan hasil lebih memilih Paslon 1 dan belum tentu memilih paslon 2. Untuk Ungaran Timur didapatkan hasil memilih Paslon 1 dan tidak memilih Paslon 2 jika dilihat dari faktor psikologis. Sedangkan untuk Kecamatan Bancak dan Ambarawa didapatkan hasil belum tentu memilih paslon 1 dan belum tentu memilih paslon dengan faktor psikologis.

Faktor domain kognitif perilaku memilih petani menunjukkan bahwa setelah ranking tiap indikator atau faktor psikologis dihitung, maka didapatkan hasil ranking antara pemilih petani yang memilih Paslon 1 atau pun paslon 2. Hasil tersebut sebagai berikut. 
Tabel 1 Faktor Domain Kognitif Perilaku Memilih

\begin{tabular}{|c|c|c|c|c|}
\hline \multicolumn{5}{|c|}{ Petani } \\
\hline No & Kecamatan & Hasil & & Hasil \\
\hline 1 & Pringapus & Memilih & Paslon 1 & $77,16 \%$ \\
\hline 2 & Pringapus & $\begin{array}{l}\text { Tidak } \\
\text { Paslon } 2\end{array}$ & Memilih & $41 \%$ \\
\hline 3 & Bergas & $\begin{array}{l}\text { Belum } \\
\text { Paslon } 1\end{array}$ & Memilih & $61 \%$ \\
\hline 4 & Bergas & $\begin{array}{l}\text { Tidak } \\
\text { Paslon } 2\end{array}$ & Memilih & $40 \%$ \\
\hline 5 & Ungaran Barat & Memilih & Paslon 1 & $78 \%$ \\
\hline 6 & Ungaran Barat & $\begin{array}{l}\text { Tidak } \\
\text { Paslon }\end{array}$ & $\begin{array}{r}\text { Memilih } \\
2\end{array}$ & $48 \%$ \\
\hline 7 & Ungaran Timur & $\begin{array}{l}\text { Belum Te } \\
\text { Memilih }\end{array}$ & $\begin{array}{l}\text { entu } \\
\text { Paslon } 1\end{array}$ & $81 \%$ \\
\hline 8 & Ungaran Timur & $\begin{array}{l}\text { Tidak } \\
\text { Paslon }\end{array}$ & $\begin{array}{r}\text { Memilih } \\
2\end{array}$ & $50 \%$ \\
\hline 9 & Bancak & $\begin{array}{l}\text { Tidak } \\
\text { Paslon }\end{array}$ & $\begin{array}{r}\text { Memilih } \\
1\end{array}$ & $51 \%$ \\
\hline 10 & Bancak & $\begin{array}{l}\text { Tidak } \\
\text { Paslon } 2\end{array}$ & Memilih & $50 \%$ \\
\hline 11 & Ambarawa & Memilih & Paslon 1 & $75 \%$ \\
\hline 12 & Ambarawa & Memilih & Paslon 2 & $83 \%$ \\
\hline
\end{tabular}

Sumber Tabel: Hasil Penelitian di Lapangan

Berdasarkan tabel tersebut, Untuk Kecamatan Bergas dihasilkan belum tentu memilih paslon 1 dan tidak memilih paslon 2. Untuk Ungaran Barat memilih paslon 1 dan belum tentu memilih paslon 2 . Sedangkan untuk Kecamatan Bancak belum tentu memilih paslon 1 dan pasti memilih paslon 2. Lalu Ambarawa didapatkan hasil memilih paslon 1 dan 2 dengan faktor domain kognitif yang artinya itu merusak jawaban.

Berdasarkan hasil penelitian perilaku memilih petani pemegang kartu tani ditemukan bahwa identifikasi figur paslon pemilih petani pemegang kartu tani melihat calon karena ikatan emosional terhadap figur sebagai hasil sosialisasi dan pencitraan kandidat. Petani sangat bangga jika pernah bertemu secara langsung dengan Ganjar Pranowo seperti yang dikemukakan oleh Sartono Ketua Kelompok Tani Mardi Rahayu Kecamatan Ungaran Barat yang mengatakan bangga karena bertemu dengan sosok Ganjar Pranowo, yang berkata "Saya sudah pernah diundang oleh Bupati untuk bertemu dengan Ganjar, Ganjar merupakan sosok yang ramah kepada petani. Analisis ini sesuai dengan pandangan Schulz (1998) yang mengatakan bahwa Political efficacy merupakan persepsi individual yang berkaitan dengan seseorang dalam mempengaruhi proses kebijakan. Perilaku timbul dari pengalaman: tidak dibawa sejak lahir, tetapi merupakan hasil belajar (Rakhmat, 2005:32).

Identifikasi parpol pengusung paslon dapat diidentifikasi dengan alasan mendasar pemilih dalam menentukan pilihan politiknya adalah sebuah visi tertentu (Solikhin, 2009). Petani pemegang kartu tanu juga merupakan bagian dari para pemilih yang ada di daerah. Pemilih di daerah tentunya memiliki corak khusus dalam menentukan hak pilihnya. Salah satunya ialah daerah masyarakat yang memiliki corak tradisional dan cenderung memilih calon yang disarankan berdasarkan panutan ulama atau kyai setempat. Terkait adanya corak perilaku pemlih yang didasarkan oleh agama disampaikan oleh ketua Gabungan Kelompok Tani (GAPOKTAN) dari Kecamatan Bergas yang bernama Toha bahwa masyarakatnya cenderung memilih tokoh NU sebagai pilihan politik karena biasanya saat ada acara NU, masyarakat dapat mengenal tokoh $\mathrm{NU}$ yang sedang mencalonkan diri sebagai paslon. NU merupakan ormas Islam yang mewadahi masyarakat dapat bertemu dengan toloh politik yang biasanya berasal dari kalangan ulama. Berdasarkan pemaparan dari Toha tersebut, sejalan dengan teori yang disampaikan oleh Robert D. Putnam dalam memandang bahwa sistem politik terdiri dari lapisan-lapisan seperti halnya stratifikasi sosial dimana salah satu lapisannya disebut kaum pemilih (voters), lapisan ini dalam sistem stratifikasi politik di negara penganut demokrasi perwakilan adalah lapisan massa warga negara biasa yang hanya bisa mempengaruhi kehidupan politik nasional ketika diselenggarakan pemilihan umum. Kaum Pemilih ini memiliki satu sumber politik kolektif penting, yaitu jumlahnya yg besar, tetapi 
sebagai individu mereka tidak mempunyai pengaruh politik sama sekali (Mas'oed 2008). Di satu sisi ada petani yang memilih Sudirman-Said-Ida Fauziah karena didukung oleh karena aktif di NU sehingga dekat dengan tokoh-tokoh PKB. Petani yang memilih brdasarkan religi disebabkan karena masih memegang teguh petuah dari kyai desa. Perilaku pemilih petani juga dipicu oleh adanya ikatan emosional antara petani pemegang kartu tani terhadap tokoh yang dihormati di lingkungannya. Hubungan emosional ini yang dipicu oleh juru kampanye saat mendekati Pemilihan Gubernur Jawa Tengah 2018. Juru kampanye dibentuk oleh para simpatisan yang dekat dengan partai politik, khususnya anggota DPR.

Menurut Ramlan Surbakti, perilaku memilih ialah proses kegiatan warga negara untuk membuat keputusan dalam politik, baik itu yaitu apakah memilih atau tidak memilih dalam pemilihan umum. Jika memilih apakah memilih partai tertentu atau memilih kandidat tertentu Surbakti, 1994). Menurut Adman Nursal Baik dalam pemilu maupun pilkada langsung semua partai politik peserta pemilu/pilkada langsung membentuk badan atau tim pemenangan atau tim sukses. Juru kampanye atau tim sukses yang bertanggung jawab atas perolehan suara partai politik maupun para kandidat. Badan/tim itu pulalah yang menentukan langkah-langkah strategis, membuat berbagai yel, membuat isu dan kontra isu, melakukan pendekatan kepada media masa dan materi serta sarana kampanye. Sejak dini mereka menyiapkan para jurkam dengan pembagian wilayah disesuaikan dengan karakter masyarakat di masingmasing wilayah (Nursal, 2004)

Apakah ada pemberian insentif atau hibah politik pada kaum petani dinilai sebagai sikap pragmatis pemilih dilakukan karena ada hubungan timbal balik dari paslon dalam meraih suara dari pemilih dengan cara menebarkan janji-janji atau bantuan politik. Kondisi masyarakat pemilih di daerah banyak yang masih sangat terbatas baik dalam aspek ekonomi maupun politik, kesempatan tersebut dimanfaatkan oleh pemilih. Dalam penelitian ini faktor tersebut disebut sebagai insentif atau adanya hibah politik. Pemberian insentif/hibah politik dalam di kalangan petani tentunya ialah bantuan peralatan pertanian, kaos, atau pun money politics. Adanya aktor trust (kepercayaan) rakyat terhadap para pemimpin daerah menjadi clean governance dan banyaknya pejabat maupun wakil rakyat yang tersangka korupsi, dapat melahirkan sikap apatisme rakyat terhadap pemimpin yang berkompetisi dalam pemilihan Pemilihan Gubernur Jawa Tengah 2018. Suatu hal yang penting dalam fenomena pemilu adalah sikap politik masyarakat. Widayatun (1999:228) menjelaskan sikap adalah kesiapan seseorang untuk bertindak.

Golongan putih petani pemegang kartu tani dalam penelitian ini merupakakan Memilih atau tidaknya seseorang sangat dipengaruhi oleh stimulus politik sebagaimana yang telah diuraikan pada pembahasan sebelumnya. Pada Kecamatan Bancak ditemukan bahwa lebih dari $50 \%$ petani dinyatakan golput. Lindenfeld menemukan faktor utama yang mendorong orang untuk berpartisipasi dalam kehidupan politik adalah kepuasan finansial. Dalam studinya, ia menemukan bahwa status ekonomi yang rendah menyebabkan seseorang merasa teralienasi dari kehidupan politik, sehingga orang tersebut bersikap apatis. Kecamatan Bancak merupakan kecamatan yang paling pedalaman dari Kabupaten Semarang, sehingga memang para petani seringkali ketinggalan informasi dan kesulitan menebus pupuk.

\section{SIMPULAN}

Untuk melihat faktor yang mempengaruhi petani pemegang kartu tani memilih Ganjar Pranowo lebih memilih (Paslon 1), di Kabupaten Semarang dengan sampel enam kecamatan yaitu Pringapus, Bergas, Ungaran Barat, Ungaran Timur, 
Bancak, dan Ambarawa ialah adanya faktor sosiologis, psikologis, rasional, domain kognitif. Dalam faktor sosiologis, adanya hubungan pertemanan dan keluarga dengan paslon atau pun partai pengusung paslon mempengaruhi perilaku pemilih petani pemegang kartu tani. Jadi dapat disimpulkan bahwa petani pemegang kartu tani tidak memilih Sudirman Said-Ida Fauziah karena petani tidak bisa mengidentifikasi Paslon 2 karena merupakan orang baru bagi para petani. Secara psikologis, petani memiliki ketertarikan emosional dengan figure Ganjar. Tapi muncul fenomena golput di beberapa kecamatan seperti di Kecamatan Bancak dan Kecamatan Ambarawa karena mereka memiliki sikap apatis kepada pilgub dan kartu tani. Secara rasional, petani juga lebih memilih Paslon 1 karena adanya bantuan-bantuan yang diterima oleh petani melalui partai pendukungnya. etani merasa diperhatikan dengan dampak program kartu tani sehingga memilih Paslon 1 jika dilihat dari segi faktor domain kognitif. Simpulannya berdasarkan penelitian yang dilakukan di lapangan diperoleh data bahwa saat ini petani pemegang kartu tanilebih memilih Paslon 1 Ganjar Pranowo-Taj Yasin meskipun di daerah tertentu ada yang tidak memilih Paslon 1 karena merasa pilgub tidak memeberikan dampak pada kehidupan petani serta rasa enggan menggunakan kartu tani. Hasil penelitian ini membuktikan bahwa kartu tani tidak hanya menjadi masalah di kalangan petani, tapi banyak petani yang merasa adanya manfaat bagi petani. Petani pemegang kartu tani di Kabupaten Semarang yang memebrikan suaranya untuk memilih Pasangan Ganjar Pranowo (Paslon 1), karena petani mengenal figur Ganjar Pranowo sebagai calon gubernur yang sebelumnya sudah mejabat sebagai gubernur atau petahana. Petani dapat mengindentifikasi paslon dari tokoh masyarakat setempat yang dihormati dan kedekatan dengan partai politik tertentu. Di satu sisi ada petani yang memilih Sudirman-Said-Ida Fauziah karena didukung oleh karena aktif di NU sehingga dekat dengan tokoh-tokoh PKB. Petani yang memilih brdasarkan religi disebabkan karena masih memegang teguh petuah dari kyai desa. Perilaku pemilih petani juga dipicu oleh adanya ikatan emosional antara petani pemegang kartu tani terhadap tokoh yang dihormati di lingkungannya. Hubungan emosional ini yang dipicu oleh juru kampanye saat mendekati Pemilihan Gubernur Jawa Tengah 2018. Juru kampanye dibentuk oleh para simpatisan yang dekat dengan partai politik, khususnya anggota DPR. Kabupaten Semarang yang ada di daerah. Terkait dengan ada atau tidaknya pemberian uang atau bantuan politik dalam pemilihan gubernur di kalangan petani.

\section{DAFTAR PUSTAKA}

Adiwilaga, A. (1992). Ilmu Usaha Tani, Bandung: Alumni.

Berita Kartu Tani. Diambil dari https://biroinfrasda.jatengprov.go.id/progra mkegiatan/kartu-tani/.

Data Petani Biro Infrastruktur dan Sumber Daya Alam Provinsi Jawa Tengah.

Dokumen Hasil Survai Pertanian Antar Sensus (Sutas) 2018 Biro Infrastruktur dan Sumber Daya Alam Provinsi Jawa Tengah.

Ellya. (2018). "Ironis Kartu Tani Dijanjikan Selesai Akhir Masa Jabatan Ganjat, diakses dari http://beritajateng.net/ironis-kartu-tanidijanjikan-selesai-akhir-jabatan-ganjar/, tanggal 15 Januari 2018.

Firmansyah. (2007). Marketing Politik: antara pemahaman dan realitas, Jakarta: Yayasan Obor. Mar'at. 1996. Sikap Manusia, Perubahan Serta Pengukurannya. Jakarta: Gramedia Widiya Pustaka Utama.

Fitriyah. (2013) Perilaku Pemilih dalam Pilkada Kudus. Jurnal Politika. Vol. 4 No.1.

Lumansyah, O. (2018). Inilah Manfaat Kartu Tani Bagi Bank dan Petani, https://industri.kontan.co.id/news/inimanfaat-kartu-tani-bagi-petani-dan-bank, tanggal 27 Januari 2018.

Mas'oed, M. \& MacAndrew, C. (2004). Perbandingan Sistem Politik, Gadjah Mada.

Mosher. (2008). Pertanian (Agrikultur), Jakarta: Bina Aksara, University Press. Yogyakarta.

Nurdin, N. (2018). "Debat Ganjar dan Sudirman Said tentang Kartu Tani" diambil dari https://regional.kompas.com/read/2018/0 
Malisa Ladini \& Yuwanto, Perilaku Memilih Pemegang Kartu Tani Pada Pemilihan Gubernur Jawa Tengah

4/21/06315441/debat-ganjar-dansudirman-said-tentang-kartu-tani, tanggal 15 Januari 2019.

Nursal, A. (2004). Politik Marketing, Strategi Memenangkan Pemilu Sebuah Pendekatan Baru Kampanye DPR, DPD, Presiden. Jakarta: PT. Gramedia.

Prastowo, A. (2012). Panduan Kreatif Membuat Bahan Ajar Inovatif. Yogyakarta: Diva Press.

Rakhmat, J. (2005). Psikologi Komunikasi. Bandung; PT. Remaja Rosdakarya Offset.

Rizkiyansyah. (2007). Mengawali Pemilu Menatap Demokrasi (Catatan Penyelenggaraan Pemilu 2004). Bandung: IDEA Publishing, Bandung.

Schultz, D. P. (1998). Psychological and Work Today: An introduction to Industrial.

Solikhin, M. (2009). "Perilaku Pemilih Buruh Rokok dalam Pilkada Langsung di Kabupaten Kudus". Tesis. Semarang. Jurnal Politika Undip. Vol. 4 No.1.
Sorensen, G. (2003). Pengantar Studi Hubungan Internasional. Terjemahan oleh Dadan Suryadipura. Yogyakarta: Pustaka Pelajar.

Sugiyono. (2010). Metode Penelitian Pendidikan. Bandung: CV. Alfabeta.

Surbakti, R. (1992). "Memahami Ilmu Politik". Jakarta: PT. Grasindo.

Syahrul, M. (2018). Petani di Semarang Tak Bisa Tebus Pupuk Bersubsidi. Diambil dari https://regional.kompas.com/read/2018/0 2/15/16375931/petani-di-semarang-takbisa-tebus-pupuk-bersubsidi, tanggal 7 Januari 2019 Pukul 13.40 WIB.

Utomo, S. (2016). Fenomena Perilaku Pemilih Pada Pilgub Jateng 2013. Jurnal Ilmu Sosial. Vol 15. No. 1.

Widayatun, T.R. (1999). Ilmu Perilaku. Jakarta: CV. Sagung Seto. 